\title{
Dynamic Response of Gradient Foams
}

\author{
L. L. Hu ${ }^{1}$ and Y. Liu \\ Department of Applied Mechanics \& Engineering, School of Engineering, Sun Yat-sen University, \\ Guangzhou, China \\ ${ }^{1}$ hulingl@mail.sysu.edu.cn
}

УДК 539.4

\section{Динамическая характеристика градиентных пеноматериалов}

\author{
Л. Л. $\mathrm{Xy}^{1}$, Й. Лиу
}

Факультет прикладной механики и машиностроения, кафедра машиностроения, Университет им. Сунь Ятсена, Чуанчжоу, Китай

С помощью численного метода исследовань динамические характеристики градиентных трехслойных пеноматериалов типа Вороного. Исследованы поглощение энергии, дистальные напряжения градиентного пеноматериала и напряжения при ударе. Установлено, что начальное максимальное напряжение при ударе и преждевременное поглощение энергии градиентного пеноматериала уменьшаются при низкой прочности первого слоя. Нежелательное влияние на поглощение энергии можно смягчить путем уменьшения толщины первого слоя. Различие между плотностью первых двух слоев необходимо контролировать в рамках предельного диапазона, чтобы избежать возникновения максимального напряжения во втором слое. Слабый дистальный слой может способствовать снижению дистального напряжения пеноматериала при высокой скорости удара, тогда как значительный градиент плотностей последних двух слоев приводит к преждевременному увеличению дистального напряжения при средней скорости удара.

Ключевые слова: градиентный пеноматериал, удар, максимальное напряжение, дистальное напряжение, поглощение энергии.

Introduction. Metallic foams have been developed in recent years and are growing in use as new engineering structural materials. The advantages of these ultra-light metal materials are not only the high relative stiffness and strength, but also the effective energy absorption during accidental impacts while limiting the crushing force [1-3]. It has been recognized that the mechanical properties of the foams are dominated by the relative density [1]. Moreover, the impact velocity has also proved to play an important role in controlling the mechanical properties of cellular materials [3-5].

In the past few years, research interest has been triggered in studying various graded cellular materials. It is shown that a density gradient could significantly change the deformation mode and the energy absorption of cellular structures [6]. Experimental results show that placing the hardest layer as the first impacted layer and the weakest layer as the last layer has some benefits in terms of maximum energy absorption with a minimum force level transmitted to the protected structures under the high-velocity impact [7]. The energy absorption capacity of the double-layer foam cladding under blast load is analytically derived based on a rigid-perfectly plastic-locking (RPPL) foam model [3], in which the gradient foam is assumed to deform in the "shock wave" mode until entirely absorbing the blast energy [8]. 
In the previous studies, insufficient attention was paid to the impact peak stress of gradient foams, which is important in case of such car accidents, as the car-to-passenger or car-to-car collisions. The damage of the bumped object depends on the peak stress during impact and on the energy absorption value: the former is required to be low and the latterhigh. However, both of these values increase with the foam density.

The present paper is focused on the impact peak stress, the energy absorption and the distal stress of the gradient foam. A method is proposed to relief the conflict between the impact peak stress and the energy absorption in designing the gradient foam. The results on the distal stress alert the deficiency of the design method on the gradient foams reported in literature.

Numerical Models. To study the dynamic properties of a graded cellular material, a finite element model is constructed using the ANSYS/LS-DYNA software. Three layers of the Voronoi-type foam with random cells are constructed with the different density of each layer. It is known that both the impact stress, and the distal stress of cellular materials increase with the material density [5, 9]. Thus, four kinds of a gradient foam with the strongest foam in the middle layer are considered in the present study, as listed in Table 1. The average relative density $\rho_{r}=\rho^{*} / \rho_{s}$ of the four kinds of gradient foams is 0.098 , where $\rho^{*}$ and $\rho_{s}$ are the density of the foam and the base material, respectively. Moreover, a nongraded foam $(\mathrm{N})$ with the relative density of 0.098 is also studied for comparison.

$\mathrm{T}$ a b 1 e 1

Physical Parameters and the Peak Stress of Foams

\begin{tabular}{|c|c|c|c|c|c||}
\hline \multirow{2}{*}{ Foam } & \multirow{2}{*}{ Layer } & \multirow{2}{*}{$\begin{array}{c}\text { Thickness } \\
(\mathrm{mm})\end{array}$} & \multirow{2}{*}{$\begin{array}{c}\text { Relative } \\
\text { density }\end{array}$} & \multicolumn{2}{|c|}{ Peak stress (MPa) } \\
\cline { 5 - 6 } & & & & $120 \mathrm{~m} / \mathrm{s}$ & $75 \mathrm{~m} / \mathrm{s}$ \\
\hline \multirow{2}{*}{$\mathrm{A}$} & 1st & 20 & 0.099 & 11.28 & 6.30 \\
& 2nd & 20 & 0.119 & 7.80 & 3.83 \\
& 3rd & 20 & 0.075 & & \\
\hline \multirow{2}{*}{$\mathrm{B}$} & 1st & 20 & 0.075 & 9.82 & 3.62 \\
& 2nd & 20 & 0.119 & 8.57 & 2.91 \\
& 3rd & 20 & 0.099 & & 1.74 \\
\hline \multirow{2}{*}{$\mathrm{C}$} & 1st & 10 & 0.055 & 5.57 & 6.18 \\
& 2nd & 40 & 0.119 & 11.34 & 3.81 \\
& 3rd & 10 & 0.055 & & 4.57 \\
\hline \multirow{2}{*}{$\mathrm{D}$} & 1st & 10 & 0.075 & 7.77 & 6.19 \\
& 2nd & 40 & 0.114 & 9.56 & \\
\hline $\mathrm{N}$ & 3rd & 10 & 0.055 & & \\
\hline
\end{tabular}

The cell wall material is assumed to be elastic/perfectly plastic with $E=68 \mathrm{GPa}$ $\sigma_{y s}=130 \mathrm{MPa}, \rho_{s}=2700 \mathrm{~kg} / \mathrm{m}^{3}$, and $v=0.3$, where $E$ and $v$ are the Young modulus and Poisson's ratio of the base material, respectively. In simulations the foam block is placed on a fixed rigid base at one end (the distal end) and crushed by a rigid plate with a constant crushing velocity $V$ ( 75 or $120 \mathrm{~m} / \mathrm{s})$ at the other end (the impact end). The first layer of the foams is always at the impact end and the third layer is always at the distal end. 
Results and Discussion. Impact Stress. Due to shock wave and inertia effects, the cells of the foam will collapse layer-by-layer from the impact end to the distal one under the high-velocity impact, such as $120 \mathrm{~m} / \mathrm{s}$, which is similar to propagation of a shock wave in a continuum bar. Here we refer to this deformation mode as a "shock wave" mode. Under the moderate-velocity impact, such as $75 \mathrm{~m} / \mathrm{s}$, the foams collapse in this "shockwave" mode in the early crushing stage, while the third layer usually begins to deform during the compression of the second layer, and even is crushed to densification before the second layer deforms completely, especially for the foams with a high density gradient between the last two layers, such as foams A, C, and D.

A typical stress-strain curve of the gradient foam is shown in Fig. 1. The stress before densification (i.e., the plateau stress) is important for the energy absorption of the foam, which is dominated by the foam density [1]. Thus, the plateau stage of the gradient foam consists of three parts, as shown in Fig. 1, while the stress level in each part depends on the density of the crushed foam layer.

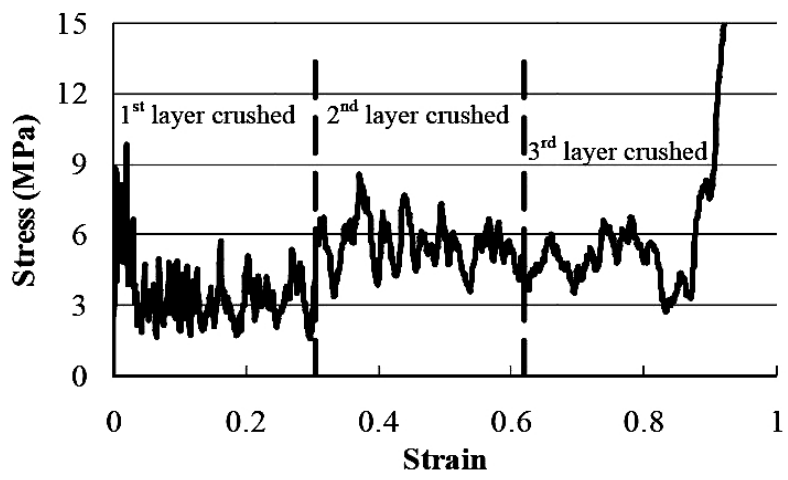

Fig. 1. A typical stress-strain curve of gradient foam B (impact velocity $120 \mathrm{~m} / \mathrm{s}$ ).

There is a peak of the stress at the initial impact, which may cause the destruction of the crushing objects in the collision accidents. For the gradient foams, the peak stress is expected to occur at the initial instant of the impact or during the crushing of the foam layer with the largest density. Since the strongest foam is placed in the middle layer in the present design, Table 1 lists the peak stress of the foams during the crushing of the first and the second layers, respectively. It is obvious that the initial impact peak stress (the first peak stress) can be obviously reduced by decreasing the foam density in the first layer. However, provided the difference between densities of the first and the second layers is large enough, the peak stress occurring in the second layer will exceed the initial one, which occurs in foams $\mathrm{C}$ and $\mathrm{D}$, as listed in Table 1 . This means that the density of the first layer should be reduced within a limit range for the purpose of reducing the peak stress of the gradient foam.

Energy Absorption. Cellular materials are frequently used in the energy absorption devices. Figure 2 plots the variety of the absorbed energy per volume (specific energy) of the foams under study versus strain. It is obvious that the energy absorption of the foams is enhanced by the impact velocity, which is exhibited by the two clusters of the energy curves according to the impact velocity, as shown in Fig. 2. This is due to the inertia effects of the foam microstructure, as discussed in $[2,9]$.

It is shown in Fig. 2 that the specific energy of the nongraded foam linearly increases with strain due to the steady plateau stress, while the energy absorption of the gradient foams undulates depending on the distribution of the foam density. As compared to a nongraded foam, there is a drop at the early stage of the energy curve for the gradient foams with a weak first layer, such as foams B, C, and D, as shown in Fig. 2. The weaker 


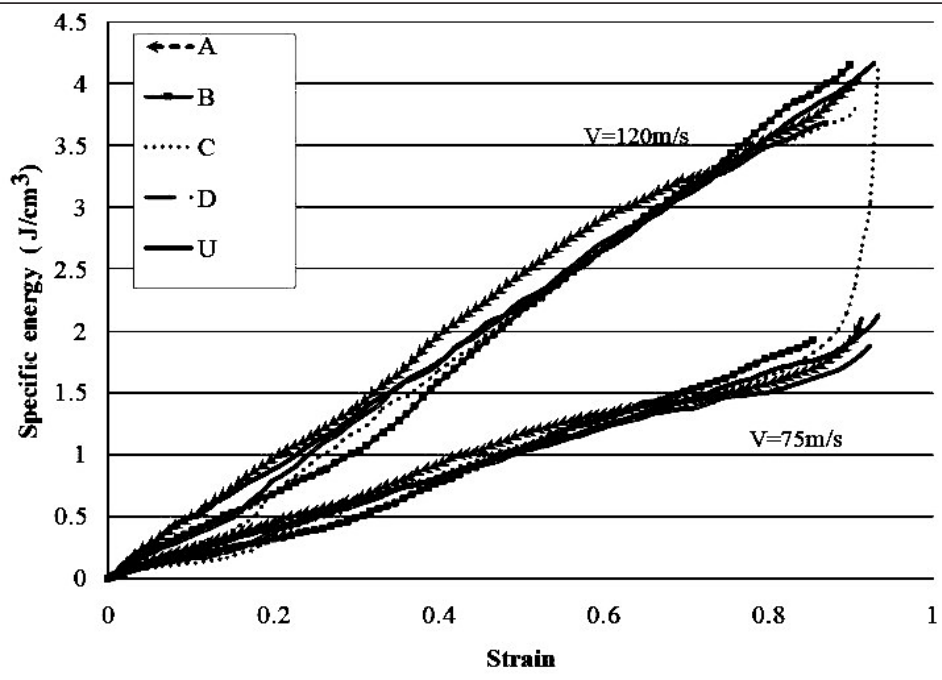

Fig. 2. Dependence of the foam specific energy on strain.

the first layer, the steeper the drop. The absorbed energy recovers to the average level, i.e., that of the nongraded foam, at the strain of about $20 \%$ for foams C and D with the $10 \mathrm{~mm}$ thickness of the first layer, and at the strain of about $40 \%$ for the foam B with the $20 \mathrm{~mm}$ thickness of the first layer, which indicates that the early energy absorption of the gradient foam can be improved by decreasing the thickness of the first weak layer while conserving the buffer function of this layer for reducing the impact peak stress.

Distal Stress. When the foams perform as the protecting devices, the stress transferred to the protected object is concentrated in the engineering applications, the level of which can be reflected with the distal stress of the foams during crushing, as shown in Fig. 3. The horizontal axis in Fig. 3 denotes the compressed strain of the foams. It is shown that the curve of the distal stress includes three stages, i.e., the elastic stage, the plateau stage and the densification stage, which is similar to that of the stress at the impact end. It is observed that the response of the distal stress manifests a delay in reference to strain, i.e., it begins at a certain (nonzero) strain, which is related to the propagation of the stress wave within the foam from the impact end to the distal one.

By comparing the densities of the gradient foams listed in Table 1 and plotting them in Fig. 3, it is shown that the distal stress level of the gradient foams is dominated by the the last layer density. A weak distal layer can effectively reduce the distal stress of the foam under impact. Under high-velocity impact, such as $120 \mathrm{~m} / \mathrm{s}$, the distal stress of the foams increases rapidly after the strain exceeds about 0.8 , which is close to the densification strain for the impact stress of the foams, as shown in Fig. 1.

It is seen from Fig. $3 \mathrm{~b}$ that, under the impact of $75 \mathrm{~m} / \mathrm{s}$, the densification strain for the distal stress of foams A, C, and D is about 0.6 or much less. By comparing the density of the last layer with that of the second one, as listed in Table 1, it is found that there is a high gradient for the three foams $\mathrm{A}, \mathrm{C}$, and $\mathrm{D}$ (the density of the last layer is by $37 \%$ lower than that of the second one in foam A, by $54 \%$ in foam C, by $52 \%$ in foam $\mathrm{D}$, and only by $17 \%$ in foam B). Under the impact with a moderate velocity, such as $75 \mathrm{~m} / \mathrm{s}$, the weak distal layer will be deformed before the second layer is compressed completely due to a high gradient between the last two layers, which leads to the early increase of the distal stress. This is more pronounced for foam $\mathrm{C}$ with the highest gradient between the last two layers, the distal stress of which increases at strain about 0.4 . More attention should be paid to the early increase in the distal stress in the industry applications, otherwise the protected object may be destroyed. 


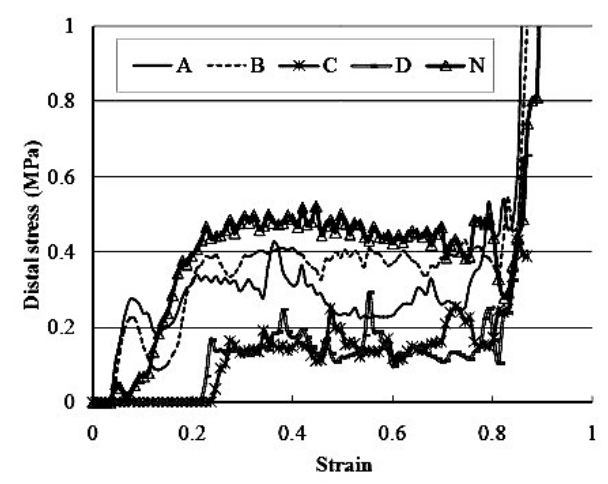

a

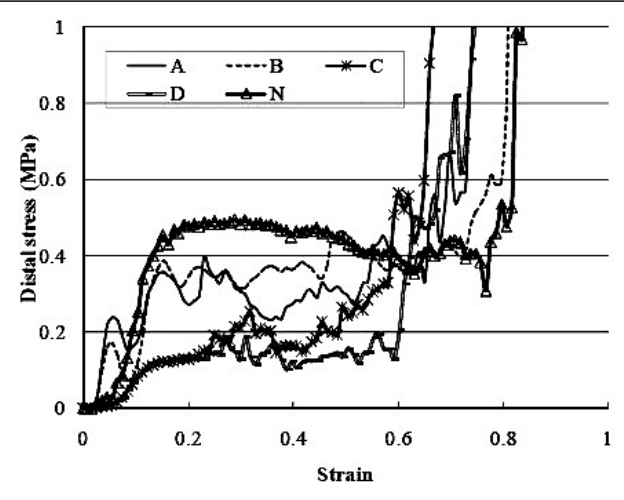

b

Fig. 3. Distal stress of the foams versus strain under the impact of 120 (a) and $75 \mathrm{~m} / \mathrm{s}$ (b).

It has been already stated that the RPPL foam model [3] was used in work [7] to design the gradient foam under blast load, in which the gradient foam is assumed to deform in the "shock wave" mode until entirely absorbing the blast energy. However, at the later stage of the foam deformation the impact velocity has dropped down since a part of the blast energy has been absorbed. Consequently, the "shock wave" mode ceases to exist with subsequent premature compression of the distal layer, which means that the RPPL model becomes no longer applicable to this case.

Conclusions. The initial impact stress of the gradient foam can be diminished by reducing the density of the first layer. However, the difference in the densities of the first and the second layers should be limited to a certain range; otherwise, the higher peak stress will appear during the crushing of the second layer with a higher density, which is even larger than the one at the initial impact.

Adopting a lower density for the first layer is beneficial for the impact stress reduction, but it leads to reduction of the energy absorption of the foams. This undesirable effect on the energy absorption can be effectively reduced by diminishing the thickness of the first layer.

A weak distal layer can effectively reduce the plateau level of the foam distal stress under impact, which means a lower stress is transferred to the protected object when the foam is used for the protection devices. However, a high density gradient between the last two layers will cause the distal layer to deform before the front layer is compressed completely under the moderate- or low-velocity impact, which would finally result in an early increase in the distal stress. More attention should be paid to this phenomenon in the industry design, since the early increase in the transferred stress may destroy the object being protected.

Acknowledgments. The authors would like to thank the support from the National Natural Science Foundation of China under Grant Nos. 11172335 and 10802100. The support from the Fundamental Research Funds for the Central Universities No. 13lgzd02 is also gratefully acknowledged.

\section{Резюме}

За допомогою числового методу досліджено динамічні характеристики градієнтних тришарових піноматеріалів типу Вороного. Досліджено поглинання енергії, дистальні напруження градієнтного піноматеріалу і напруження під час удару. Установлено, що початкове максимальне напруження під час удару і передчасне поглинання енергії градієнтного піноматеріалу зменшуються за низької міцності першого шару. 
Небажаний вплив на поглинання енергії можна зм'якшити шляхом зменшення товщини першого шару. Різницю між щільністю перших двох шарів необхідно контролювати у межах граничного діапазону, щоб запобігти виникненню максимального напруження у другому шарі. Слабкий дистальний шар може сприяти зниженню дистального напруження піноматеріалу за високої швидкості удару, в той час як значний градієнт щільностей останніх двох шарів призведе до передчасного збільшення дистального напруження при середній швидкості удару.

1. L. J. Gibson and M. F. Ashby, Cellular Solids: Structure and Properties, 2nd edition, Cambridge University Press (1999).

2. L. L. Hu and T. X. Yu, "Dynamic crushing strength of hexagonal honeycombs," Int. J. Impact. Eng., 37, 467-474 (2010).

3. P. J. Tan, S. R. Reid, J. J. Harrigan, et al., "Dynamic compressive strength properties of aluminium foams. Part II - 'Shock' theory and comparison with experimental data and numerical models," J. Mech. Phys. Solids, 53, 2206-2230 (2005).

4. L. L. Hu, T. X. Yu, Z. Y. Gao, and X. Q. Huang, "The inhomogeneous deformation of polycarbonate circular honeycombs under in-plane compression," Int. J. Mech. Sci., 50, No. 7, 1224-1236 (2008).

5. L. L. Hu, F. F. You, and T. X. Yu, "Effect of cell-wall angle on the in-plane crushing behaviour of hexagonal honeycombs," Mater. Design, 46, 511-523 (2013).

6. A. Ajdari, H. Nayeb-Hashemi, and A. Vaziri, "Dynamic crushing and energy absorption of regular, irregular and functionally graded cellular structures," Int. J. Solids Struct., 48, 506-516 (2011).

7. H. B. Zeng, S. Pattofatto, H. Zhao, et al., "Impact behavior of hollow sphere agglomerate with density gradient," Int. J. Mech. Sci., 52, 680-688 (2010).

8. G. W. Ma and Z. Q. Ye, "Dynamic crushing behavior of random and functionally graded metal hollow sphere foams," Int. J. Impact. Eng., 34, 329-347 (2007).

9. L. L. Hu and T. X. Yu, "Mechanical behavior of hexagonal honeycombs under low-velocity impact - theory and simulations," Int. J. Solids Struct., 50, 3152-3165 (2013). 